University of Montana

ScholarWorks at University of Montana

$2-2002$

\title{
Snail Kite Nest Success and Water Levels : A Reply to Beissinger and Snyder
}

Victoria J. Dreitz

University of Montana - Missoula, victoria.dreitz@cfc.umt.edu

Robert E. Bennetts

Florida \& Caribbean Science Center, Gainesville, FLorida

Brian Toland

Toland Environmental Consulting, Melbourne, Florida

Wiley M. Kitchens

United States Geological Survey

Michael W. Collopy

University of Nevada - Reno

Follow this and additional works at: https://scholarworks.umt.edu/wildbio_pubs

Part of the Life Sciences Commons

Let us know how access to this document benefits you.

\section{Recommended Citation}

Dreitz, Victoria J.; Bennetts, Robert E.; Toland, Brian; Kitchens, Wiley M.; and Collopy, Michael W., "Snail Kite Nest Success and Water Levels : A Reply to Beissinger and Snyder" (2002). Wildlife Biology Faculty Publications. 62.

https://scholarworks.umt.edu/wildbio_pubs/62

This Article is brought to you for free and open access by the Wildlife Biology at ScholarWorks at University of Montana. It has been accepted for inclusion in Wildlife Biology Faculty Publications by an authorized administrator of ScholarWorks at University of Montana. For more information, please contact scholarworks@mso.umt.edu. 
The Condor 104:216-221

(C) The Cooper Ornithological Society 2002

\section{SNAIL KITE NEST SUCCESS AND WATER LEVELS: A REPLY TO BEISSINGER AND SNYDER}

\author{
Victoria J. Dreitz ${ }^{1,6}$, Robert E. BENNETTS ${ }^{2}$, BRIAN \\ TOLAND ${ }^{3}$, Wiley M. KitCHENS ${ }^{4}$, AND MichaEl W. \\ COLLOPY $^{5}$
}

${ }^{1}$ Natural Resources Ecology Laboratory, Colorado

State University, Fort Collins, CO 80523

${ }^{2}$ Florida \& Caribbean Science Center, $7920 \mathrm{NW} 71$ st

St., Gainesville, FL 32653

${ }^{3}$ Toland Environmental Consulting, 4545 Rivermist

Drive, Melbourne, FL 32935

${ }^{4}$ U.S. Geological Survey/Biological Resources

Division, Florida Cooperative Fish and Wildlife

Research Unit, University of Florida, Gainesville, FL

32611

${ }^{5}$ Department of Environmental and Resource

Sciences, University of Nevada, Reno, NV 89512

Abstract. Beissinger and Snyder present a commentary on our recent paper on spatial and temporal variability in nest success of Snail Kites (Rostrhamus sociabilis) in Florida (Dreitz et al. 2001). Beissinger and Snyder reanalyze a subset of data presented in our original paper to show that water levels have a significant influence on nest success. To make their argument, the authors conduct separate analyses for 5 of the original 11 wetlands; including only those having the most data. We agree with Beissinger and Snyder that water levels can affect nest success in some areas or years, as we stated in Dreitz et al. (2001). However, the purpose of our original paper was to examine the influences of nest success over broad spatial and temporal scales. When viewed in this context, using a meta-analysis, water levels alone explain only a small amount of the observed variation in nest success. One of the advantages of using a meta-analysis is that it uses all of the available data to provide an indication of the overall magnitude of an effect, which can easily be misinterpreted when viewed in a narrower context of individual study sites. We discuss the management implications of these alternative perspectives on water levels in light of their effect on habitat quality and persistence.

Key words: endangered species, Florida, information criterion, management implications, nest success, Rostrhamus sociabilis, Snail Kite, water levels.

Éxito de Nidificación de Rostrhamus sociabilis y Nivel del Agua: Respuesta a Beissinger y Snyder

Resumen. Beissinger y Snyder presentan un comentario sobre nuestro reciente trabajo que considera la

Manuscript received 9 November 2001; accepted 14 November 2001.

${ }^{6}$ E-mail: vdreitz@nrel.colostate.edu variación espacial y temporal en el éxito de nidificación de Rostrhamus sociabilis en Florida (Dreitz et al. 2001). Beissinger y Snyder reanalizan un subconjunto de los datos presentados en nuestro trabajo original para mostrar que el nivel del agua tiene una influencia significativa en el éxito de nidificación. Para elaborar su argumento, los autores analizan separadamente 5 de los 11 humedales originales, incluyendo solamente aquellos con mayor cantidad de datos. Estamos de acuerdo con Beissinger y Snyder en que el nivel del agua puede afectar el éxito de nidificación en algunas áreas o años, como exponemos en Dreitz et al. (2001). Sin embargo, el propósito original de nuestro trabajo fue examinar los factores que influencian el éxito reproductivo a una escala espacial y temporal amplia. Vista de este modo, usando un meta-análisis, el nivel del agua por separado explica solamente una pequeña cantidad de la variación observada en el éxito de nidificación. Una de las ventajas de usar un meta-análisis es que utiliza todos los datos disponibles para indicar la magnitud global de un efecto, el cual puede ser fácilmente malinterpretado cuando es visto en un contexto másacotado basado en sitios de estudio individuales. Discutimos las implicancias de manejo de estas perspectivas alternativas sobre el nivel del agua en relación a su efecto sobre la calidad del hábitat y la persistencia.

Beissinger and Snyder commented on our evaluation of the spatial and temporal variability of nest success of Snail Kites (Rostrhamus sociabilis) in Florida (Dreitz et al. 2001). The authors challenged our conclusions largely based on a reanalysis of data presented in Dreitz et al. (2001). For this reanalysis, Beissinger and Snyder partitioned a subset of the data into selected local regions, and conducted separate analyses for each region. This approach was contrary to the objective of the meta-analysis of our original paper, which focused on the effects of nest success over a broad spatial and temporal scale. The authors raise several interesting points in their commentary. We agree with some points, although we believe several others are based on misinterpretations, or faulty arguments. We attempt throughout this reply to (1) point out issues we agree with in the commentary, (2) clarify issues we believe were incorrectly interpreted, and (3) present counter-arguments where we believe Beissinger and Snyder are incorrect.

\section{VALIDITY OF THE STATISTICAL ANALYSES}

We are concerned that in order to show the effects of water levels, the authors (1) omitted several areas ( $n$ $=175$ nests) from their analysis, (2) partitioned a single analysis into five separate analyses, without adjusting the $\alpha$-level (e.g., Fowler 1990), and (3) did not address the effects of sample size and outliers on their results. Although the authors emphasize that such measures were justified, there can be a tendency for observers to find the results they expect (Balph and Balph 1983). Perhaps even more importantly, we believe Beissinger and Snyder overlooked an important reason for conducting a meta-analysis: that ecological phenomena measured at local sites or over short time 
scales can yield dramatically different results at broader scales. A meta-analysis makes use of all available data to indicate the overall magnitude of an effect (e.g., water levels), which can easily be misinterpreted when viewed within the narrower context of individual sites or studies (Gurevitch et al. 1992).

Beissinger and Snyder chose to conduct a large part of their analysis using linear regressions of the annual estimates for a subset of areas. The linear regression approach used by Beissinger and Snyder is intuitively appealing because it is a well-known statistic. However, in the context it was used, the linear regression approach masks the effects of sample size, because each point in the regression is an annual estimate for a given area, regardless of the number of nests (i.e., sample size) represented by that estimate. For example, in Water Conservation Area (WCA)-3A (the area with the highest overall number of nests) the annual estimate for 1981 was based on only 5 nests, whereas other years (e.g., 1987) were based on as many as 210 nests. If differences in sample size are taken into account using a weighted regression, the coefficient of determination $\left(R^{2}\right)$ for WCA-3A diminishes from the 0.67 reported by Beissinger and Snyder to 0.10 , and the statistical significance drops from $P<0.001$ to $P$ $=0.31$. An additional problem is that the results for some areas were strongly influenced by one extremely dry year (1981). If this outlier year is removed from the data, then the significance of WCA-3A drops even more $\left(R^{2}=0.03, P=0.62\right)$. In contrast to WCA-3A, WCA-2B and Lake Okeechobee retained a positive correlation after correcting for sample size. Two other areas excluded by Beissinger and Snyder (WCA-2A and Lake Tohopekaliga) had nonsignificant but negative correlations with water levels.

We used logistic regression to analyze our data because the success or failure of a nest can be considered a binomial result. Logistic regression analysis avoids the bias of cryptic sample size, as each year and area are essentially weighted by the inverse of the variance in such a way that years or areas with large samples have more weight than those with small samples. As stated above, the linear regression approach, as used by Beissinger and Snyder, gives equal weight to all years; thus, it does not take into account sample size.

\section{MODEL BUILDING, SELECTION, AND TESTING}

When developing our suite of candidate models, we followed the philosophy of a priori modeling. First, a global model (e.g., saturated model) is developed which includes all potentially relevant effects (Burnham and Anderson 1998). This model is used to determine, through examining residuals, the acceptability of the fit of the data. If the global model is judged acceptable, the analysis can proceed (Burnham and Anderson 1998). Other biologically relevant models can then be derived that (1) contain fewer parameters than the global model and (2) are special cases or contain nested components of the global model.

As Beissinger and Snyder point out, the global model in all studies has a lower log-likelihood than all other candidate models. However, the information criterion (AICc) approach we used does not imply that the global model is the "best" model. Rather, this ap- proach is based on the principle of parsimony, and includes parameters in a model only when they account for major components of variation in the data (Box and Jenkins 1970, Lebreton et al. 1992). Thus, a model with higher log-likelihood than the global model can, and often is, selected as the "best approximating" model (e.g., Burnham et al. 1987, Lebreton et al. 1992).

Beissinger and Snyder state that we neglected to account for "spatial variation in the manner that water levels affect nest success" in our suite of candidate models. They conclude that we should have derived an a priori model containing the interaction of Area and Water. We disagree. The water indices we derived were year and area-specific, so that adding water and the interaction of Area $\times$ Water to year and area effects risks multicollinearity (i.e., redundancy), which can then result in problems with standard errors, model coefficients, and test statistics (Glanz and Slinker 1990). It was our intention to determine if water levels acted as a proxy for area and year effects. We rejected this hypothesis because models with water levels in lieu of area and year effects were among the worst models based on AICc criteria (Dreitz et al. 2001, Table 2).

\section{DO WATER LEVELS INFLUENCE NEST SUCCESS?}

Beissinger and Snyder stated that Dreitz et al. (2001) concluded "nest success is unrelated to water levels," and a major theme throughout their commentary was to show this conclusion to be false. We believe that this was an inaccurate portrayal of our conclusions and agree that water levels may affect Snail Kite nest success. We explicitly stated (Dreitz et al. 2001:507) that our results did not imply that low water levels do not influence nest success, and that we agreed with previous reports that nest success can be substantially reduced during low water events. Where we disagree with Beissinger and Snyder is regarding the explanatory power of water level effects on nest success over broader scales. When considered in a broad context, using a meta-analysis, the explanatory power of water levels is weak. Using the linear regression approach of Beissinger and Snyder, the variation explained by water levels over the entire data set is not very impressive $\left(R^{2}=0.13\right)$. Using logistic regression, the explanatory power becomes even less (generalized $R^{2}=0.02$ ). Thus, although we agree with Beissinger and Snyder that water levels may influence nest success, our results indicated that the spatial and temporal variation in nest success was substantially greater than could be explained by water levels alone.

\section{ARE FEW NESTS AFFECTED BY WATER LEVELS?}

Dreitz et al. (2001) concluded that relatively few nests were affected by low water events, as only 18 of 1541 nests experienced such events. Beissinger and Snyder agree that relatively few nests are affected by low water levels, although they suggest that we underestimated this number because we defined a nesting attempt as beginning with the first egg. We see two issues here: (1) is it appropriate to exclude nests that were abandoned before egg laying in a demographic 
assessment? and (2) did we exclude a large number of nests that were affected by low water levels?

Should nests that fail before egg laying be included in a demographic assessment? We agree that nests that fail before egg laying are of considerable biological interest, but we disagree that it is essential to include these nests in a demographic assessment of fecundity. Estimates of fecundity can be made using nesting attempts either before or after eggs have been laid, provided that the definition of a nesting attempt is consistent for each of the subparameters estimated. We prefer to define nest attempts as we did, for the reasons stated below.

Defining a nesting attempt prior to egg laying for the purposes of estimating nest success is ambiguous, especially since males begin nest building as part of courtship (Beissinger 1988, Bennetts et al. 1988). Beissinger and Snyder suggest that nest building is characterized by socially monogamous associations, although Beissinger (1988:154) stated that "males may begin nest building or defending a potential site from other males before securing a mate." Bennetts and Kitchens (1997a) observed one radio-tagged male initiate courtship (including nest building) with five different females before a clear pair bond was established that resulted in egg laying. Second, even established pairs may terminate and resume nest building (often at a different site) during the passage of cold fronts (Beissinger 1988, Bennetts et al. 1994, Bennetts and Kitchens 1997a). Finally, contrary to Beissinger and Snyder's suggestion that abandonment of nests during nest building was not attributable to disturbance by researchers, our experience (based on observations at $>1800$ nests) is that Snail Kites, like many other raptors (e.g., Grier and Fyfe 1987, Steenhof 1987), can be quite sensitive to disturbance before eggs have been laid (Bennetts and Kitchens 1997a). We believe that disturbance by researchers during this sensitive stage can cause abandonment of nests.

Did we omit a large number of nests that were affected by low water levels by excluding these nests? Beissinger and Snyder point out that we used only 254 of 666 nests from Snyder et al. (1989) in our analysis, omitting nearly half of the nests found during low water conditions. This statement is misleading. By the authors' own account (Snyder et al. 1989, Table 2), only 62 nests were found during nest building during low water years, and the majority of these $(n=39)$ were found on northern lakes (e.g., Tohopekaliga and Kissimmee) during 1982, when local water levels were not exceptionally low. This issue is further confounded because many of the "failed" nests found during low water conditions suffered from structural collapse. Nests found tipping over were placed in artificial nest baskets and assumed to have failed, even though many succeeded (Snyder et al. 1989). Although the authors correctly recognized that providing structural support for weakened nests would bias their estimates high, it is also true that considering all of them to have failed would have biased their estimates low.

\section{ARE LOW WATER EVENTS RARE AND ARE THEIR IMPACTS ON NESTING MINIMAL?}

Are low water events rare? Beissinger and Snyder state that we concluded that low water events are rare.

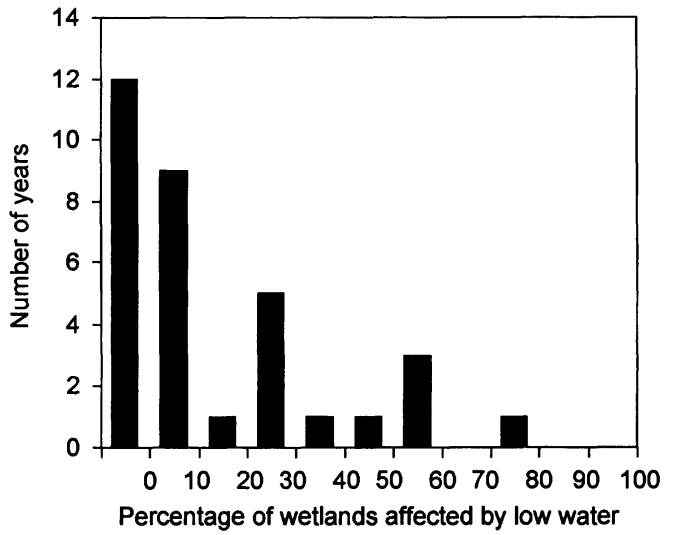

FIGURE 1. The extent to which low water events were widespread among 13 south Florida wetlands used by Snail Kites over a 33-year period (19651997), as indicated by the number of years in which wetlands experienced concurrent low water events.

Again, we suggest that this is an inaccurate portrayal of our conclusions. Although "rare" and "common" are subjective judgments, we agree with Beissinger and Snyder that high and low water events are common. The difference in our perspectives is that we believe it is rare for these events to encompass the entire range of Snail Kites in Florida. Beissinger and Snyder also argued that we presented no comprehensive data regarding the frequency of local versus widespread events. Such an analysis, although beyond the scope of Dreitz et al. (2001), was presented in a technical report (Bennetts and Kitchens 1997a). Beissinger and Snyder cited this report as evidence of the widespread nature of low water events. Unfortunately, the evidence presented was a selected subset of among-year correlations, ranging from $r=0.53$ to 0.86 (Bennetts and Kitchens 1997a:121), from three wetlands in proximity. Correlations from all the wetlands used by Snail Kites ranged from -0.15 to 0.86 , and were presented to illustrate that correlations are high for wetlands in the same drainage basin and in proximity (e.g., the subset presented by Beissinger and Snyder), but are low or even negatively correlated for wetlands in different drainage basins.

We further evaluated the relationship between frequency and spatial extent of low water events (an event was defined in Dreitz et al. [2001] as being $\geq 1$ $\mathrm{SD}$ below the mean of the annual minimum water levels) over a 33-year period from 1965-1997, in the 13 wetlands for which we had data available. For each year, we tallied the number of wetlands meeting our criteria for a low water event and plotted a frequency distribution (Fig. 1). Like most disturbance processes, the frequency and spatial extent of low water events were not independent (see also Delcourt et al. 1983). Localized low water events occurred at a relatively high frequency, while widespread droughts that encompassed all or most of the Snail Kite's range in Florida occurred much less frequently (see also MacVicar and Lin 1984, Duever et al. 1994, Bennetts and Kitch- 
ens 1997a, 1997b). Each year, low water events were most frequently localized (i.e., in $<10 \%$ of the wetlands; Fig. 1). Low water events encompassed $>50 \%$ of the wetlands in only 4 of the 33 years, and only once did such an event encompass $>60 \%$ of the wetlands.

Are impacts of low water on nesting minimal? Beissinger and Snyder suggest that we greatly underestimated the importance of low water conditions because we neglected important components of fecundity. We agree that estimates of annual fecundity require estimation of additional parameters. However, the scope of our paper was limited to one component of fecundity, nest success. We also stated (Dreitz et al. 2001: $507)$ that our results do not preclude effects on other reproductive parameters. Beissinger and Snyder state that "The low water levels of 1981 were devastating to the productivity of the population." However, Beissinger (1995:625) conducted a sensitivity analysis for population change of Snail Kites that addressed the relative importance of reproduction during low water years. Not surprisingly for a long-lived species such as Snail Kites, this analysis indicated that changes in population size were generally much more sensitive to survival (with sensitivity values up to 70 ), particularly for adults, than reproduction. But the author also found that reproduction during drought (i.e., low water) years had a sensitivity value of 0.0 for both adults and subadults. Beissinger (1995:626) emphasized this result by stating that "only changes in adult reproduction capacity during high water years affected the results." Thus, although we agree with Beissinger and Snyder that a complete assessment of fecundity requires the estimation of parameters in addition to nest success, we also believe that the overall importance of decreased reproduction during periodic low water events for this long-lived species has been overemphasized.

\section{MANAGEMENT IMPLICATIONS}

Beissinger and Snyder suggest that a model with only area and year terms (including the interaction) is difficult to interpret ecologically. We share this concern; however, we also believe that increased interpretability, while certainly desirable, should not be a criterion for selecting a model that explains little of the overall variation. We also find the alternative model proposed by Beissinger and Snyder equally difficult to interpret. Like our selected model, their proposed model contains an area and year term, but includes water levels and an Area $\times$ Water interaction term. If we examine the contribution of the individual terms in Beissinger and Snyder's proposed model using likelihood-ratio statistics, addition of the water term alone is only marginally significant $\left(\chi^{2}=3.5, P=0.06\right)$. Most of the statistical significance of water comes from its interaction with area $\left(\chi^{2}=16.7, P<0.001\right)$. This interaction term of Area $X$ Water is likely a result that some areas showed a positive association with water levels, whereas others showed a negative association. The authors speculate that WPBWCA might have water levels too deep for Snail Kites to forage (an assertion with which we disagree based on recorded water levels and our extensive observations of foraging birds), and that answers may become clearer with additional years of study. With a sample of 1541 nests of an endangered species for 22 years and 11 areas, it is hard to imagine that the controversies will easily be resolved with a few more years of research. There may also be a tendency for scientists to seek simple solutions for managing ecological systems by focusing on a single target variable (Holling 1995, Doerner 1996, Holling and Meffe 1996), even when the data indicate that such a reductionist perspective is not justified. Contrary to the suggestion of Beissinger and Snyder that more data may be needed to understand the effect of water levels on nest success, the addition of data generally leads to increasingly complex models as more parameters are supportable by the data (Burnham and Anderson 1998).

The authors also suggest that our conclusions could be interpreted to mean that we consider the effects of low water on Snail Kites to be trivial. To avoid any such confusion, we state unequivocally that we believe that low water levels have a profound effect on Snail Kites. We do not, however, recommend, the exclusion of periodic low water events to protect a few nests. Rather, we believe that periodic drying events (and periodic high water events) are vital for maintaining the vegetation communities that comprise high quality habitat (Bennetts and Kitchens 1997a, 1997b, Bennetts et al. 1998, Kitchens et al. 2002). Until recently, there has been a paradigm that portrays periodic "droughts" as having catastrophic effects on Snail Kite populations (Bennetts et al. 1998). The management recommendations resulting from this paradigm have focused on maintaining (i.e., stabilizing) wetlands under a high water regime, but stabilized high water regimes have led to severe habitat degradation (reviewed by Kitchens et al. 2002). Beissinger and Snyder point out (see also Snyder et al. 1989:305) that one of the primary causes of nest failure is structural collapse of nests placed in herbaceous sites, and more nests collapse under low water conditions. However, under periods of prolonged inundation without periodic drying events, these habitats lose the woody vegetation used as nesting substrates (Bennetts et al. 1994, 1998, Kitchens et al. 2002). Beissinger and Snyder further indicate that the problems with nesting in herbaceous vegetation are less prevalent in the Everglades because of the widespread distribution of woody vegetation. The authors overlook that prolonged inundation in the Everglades and other south Florida wetlands has resulted, and still is resulting, in the dramatic loss of woody vegetation (McPherson 1973, Worth 1983, Sklar and van der Valk, in press).

An alternative strategy to stabilized high water levels, which we believe is consistent with the natural dynamics and maintains the vegetation communities (Bennetts and Kitchens 1997a, 1997b, Bennetts et al. 1998, Kitchens et al. 2002), is managing with the viewpoint that these wetlands function as a habitat network. Across this network, the natural asynchrony of rainfall patterns, in combination with the nomadic tendencies of this species, buffers the demographic effects of water level fluctuations (Den Boer 1968, 1981), while allowing periodic drying and flooding to rejuvenate the habitat over long temporal and broad spatial scales. Thus, while we agree entirely with Beissinger 
and Snyder that widespread regional droughts have demographic consequences, this should not be a justification for overlooking the much more frequent localized events, which are an integral and necessary part of the functioning of the central and south Florida hydroscape.

We thank Emmanuelle Cam, Patricia L. Kennedy, Julien Martin, and James D. Nichols for their helpful discussions and comments on this manuscript. This is Florida Agricultural Experiment Station, Journal Serie No. R-08529.

\section{LITERATURE CITED}

BAlPh, D. F., AND M. H. Balph. 1983. On the psychology of watching birds: the problem of observer-expectancy bias. Auk 100:755-757.

BEISSINGER, S. R. 1983. Nest failure and demography of the Snail Kite: effects of Everglades water management. Annual Report to the U.S. Fish and Wildlife Service. University of Michigan, Ann Arbor, MI.

BEISSINGER, S. R. 1986. Demography, environmental uncertainty, and the evolution of mate desertion in the Snail Kite. Ecology 67:1445-1459.

BEISSINGER, S. R. 1988. The Snail Kite, p. 148-165. In R. S. Palmer [ED.], Handbook of North American birds. Vol. 4. Yale University Press, New Haven, CT

BEISSINGER, S. R. 1995. Modeling extinction in periodic environments: Everglades water levels and Snail Kite population viability. Ecological Applications 5:618-631.

BEISSINGER, S. R., AND N. F. R. SNYDER. 2002. Water levels affect nest success of the Snail Kite in Florida: AIC and the omission of relevant candidate models. Condor 104:208-215.

Bennetts, R. E., M. W. Collopy, and S. R. BeissinGER. 1988. Nesting ecology of Snail Kites in Water Conservation Area 3A. Department of Wildlife and Range Science, University of Florida, Florida Cooperative Fish and Wildlife Research Unit Technical Report No. 31, Gainesville, FL.

Bennetts, R. E., M. W. Collopy, AND J. A. Rodgers JR. 1994. The Snail Kite in the Florida Everglades: a food specialist in a changing environment, $p$. 507-532. In S. M. Davis and J. C. Ogden [EDS.], Everglades: the ecosystem and its restoration. St. Lucie Press, Delray Beach, FL.

BennetTs, R. E., AND W. M. KITCHEns. 1997a. The demography and movements of Snail Kites in Florida. Florida Cooperative Fish and Wildlife Research Unit Technical Report No. 56, Gainesville, FL.

Bennetts, R. E., AND W. M. KITChens. 1997b. Population dynamics and conservation of Snail Kites in Florida: the importance of spatial and temporal scale. Colonial Waterbirds 20:324-329.

Bennetts, R. E., W. M. Kitchens, and D. L. DeANGELIS. 1998. Recovery of the Snail Kite in Florida: beyond a reductionist paradigm. Transactions North American Wildlife and Natural Resources Conference 63:486-501.

Box, G. E. P., AND G. M. JEnkins. 1970. Time series analysis: forecasting and control. Holden Day, San Francisco, CA.

Burnham, K. P., AND D. R. Anderson. 1998. Model selection and inference: a practical-theoretic approach. Springer-Verlag, New York.

Burnham, K. P., D. R. Anderson, G. C. White, C. BrownIE, AND K. H. Pollock. 1987. Design and analysis methods for fish survival experiments based on release-recapture. American Fisheries Society Monograph 5, Bethesda, MD.

Delcourt, H. R., P. A. Delcourt, and T. WebB III. 1983. Dynamic plant ecology: the spectrum of vegetational change in space and time. Quaternary Science Reviews 1:153-175.

$\rightarrow$ Den BoER, P. J. 1968. Spreading of risk and stabilization of animal numbers. Acta Biotheoretica 18: 165-194.

$\rightarrow$ Den Boer, P. J. 1981. On the survival of populations in a heterogeneous and variable environment. Oecologia 50:39-53.

DOERNER, D. 1996. The logic of failure: recognizing and avoiding error in complex situations. Addison-Wesley, Reading, MA.

Dreitz, V. J., R. E. Bennetts, B. Toland, W. M. Kitchens, AND M. W. Collopy. 2001. Spatial and temporal variability in nest success of Snail Kites in Florida: a meta-analysis. Condor 103:502-509.

Duever, M. J., J. F. Meeder, L. C. MeEder, AND J. M. McCollom. 1994. The climate of South Florida and its role in shaping the Everglades ecosystem, p. 255-248. In S. M. Davis and J. C. Ogden [EDS.], Everglades: the ecosystem and its restoration. St. Lucie Press, Delray Beach, FL.

Fowler, N. 1990. The 10 most common statistical errors. Bulletin of the Ecological Society of America 71:161-164.

Glanz, S. A., And B. K. Slinker. 1990. Primer of applied regression and analysis of variance. McGraw-Hill, New York.

Grier, J. W., AND R. W. FyFE. 1987. Preventing research and management disturbance, p. 173-182. In B. A. G. Pendleton, B. A. Milsap, K. W. Cline, and D. M. Bird [EDS.], Raptor management techniques manual. National Wildlife Federation, Washington, DC.

Gurevitch, J., L. Morrow, A. Wallace, and J. S. WALSH. 1992. A meta-analysis of competition in field experiments. American Naturalist 140:539 572.

Holling, C. S. 1995. What barriers? What bridges?, p. 3-34. In L. H. Gunderson, C. S. Holling, and S. S. Light [EDS.], Barriers and bridges to the renewal of ecosystems and institutions. Columbia University Press, New York.

Holling, C. S., AND G. K. Mefre. 1996. Command and control and the pathology of natural resource management. Conservation Biology 10:328-337.

KITCHENS, W. M., R. E. BENNETTS, AND D. L. DEANGELIS. 2002. Linkages between the Snail Kite population and wetland dynamics in a highly fragmented south Florida hydroscape, p. 183-203. In J. W. Porter and K. G. Porter [EDS.], The Everglades, Florida Bay, and coral reefs of the Florida Keys: an ecosystem sourcebook. CRC Press, Boca Raton, FL. 
Lebreton, J. D., K. P. Burnham, J. Clobert, and D. R. ANDERSON. 1992. Modeling survival and testing biological hypotheses using marked animals: a unified approach with case studies. Ecological Monographs 62:67-118.

MACVICAR, T. K., AND S. S. T. Lin. 1984. Historical rainfall activity in central and southern Florida: average, return period estimates and selected extremes, p. 477-509. In P. J. Gleason [ED.], Environments of South Florida past and present II. Miami Geological Society, Miami, FL.

MCPherson, B. F. 1973. Vegetation in relation to water depth in Conservation Area 3, Florida. Open File Report, U.S. Geological Survey, Tallahassee, FL.

SKLAR, F. H., AND A. VAN DER VALK. In press. Tree islands of the Everglades: an overview. In A. van der Valk and F. H. Sklar [EDS.], Tree islands of the Everglades. Kluwer Academic Press, Netherlands. SNYDER, N. F. R., S. R. BEISSINGER, AND R. CHANDleR. 1989. Reproduction and demography of the Florida Everglade (Snail) Kite. Condor 91:300-316.

SteENHOF, K. 1987. Assessing raptor reproductive success and productivity, p. 157-170. In B. A. G. Pendleton, B. A. Milsap, K. W. Cline, and D. M. Bird [EDS.], Raptor management techniques manual. National Wildlife Federation, Washington, DC.

WorTH, D. 1983. Preliminary responses to marsh dewatering and reduction in water regulation schedule in Water Conservation Area-2A. Technical Publication 83-6. South Florida Water Management District, West Palm Beach, FL. 